\title{
THE RECEDING HORIZON OF DEMOCRACY
}

\author{
JAMES T. KLOPPENBERG \\ Department of History, Harvard University \\ E-mail: jkloppen@fas.harvard.edu
}

When I began work on Toward Democracy more than twenty years ago, I planned to write a short book explaining how and why ideas about selfgovernment developed in European and American thought from the middle of the eighteenth century to the present. Teaching courses and writing articles on republican, liberal, and democratic ideas, I found thinkers reflecting again and again on searing experiences of fratricidal violence, and as a result the theme of civil war became more prominent in my understanding of democracy. ${ }^{1}$ Had my analysis begun in the eighteenth century, I would have missed-as US historians often do- the shaping force of the devastating sixteenth-century wars of religion, the murderous mid-seventeenth-century English Civil War, and the less violent but no less crucial English revolution of 1688. Attempts to establish non-monarchical regimes, or even to modify monarchies to include elements of popular participation, foundered for multiple reasons, but among them were recollections of the carnage that ordinary people repeatedly inflicted on other ordinary people. Misgivings about democracy did not only arise from cultural conservatism or reverence for hierarchy. They also were forged in irrepressible memories of savagery.

If those still-tender scars helped explain fears of democracy, why did some people persist in calling for popular government rather than acquiescing in royal absolutism? From the first glimmerings of resistance theory in late medieval city-states through the experiments in popular government that the founders of some early New England colonies called "democracie," the sources I was reading pulled me back into earlier debates about the limits and possibilities of self-rule, which often drew from ancient Greek or Roman authors, or from Hebrew and Christian scriptures. Toward Democracy, which examines many contributors to

See David Armitage, Civil Wars: A History in Ideas (New York, 2017). 
European and American democratic theory from the ancient world through the end of the nineteenth century, is the result.

\section{$* * *$}

I thank the editors of Modern Intellectual History for organizing this forum and Richard Bourke, Annelien de Dijn, Daniel T. Rodgers, and Caroline Winterer for their essays. I appreciate their perseverance in following the many threads that run through the book. I am grateful to Rodgers for characterizing it as four books: a narrative account, a comparative analysis, an intellectual history, and an inquiry into the ethical dimensions of democracy. That description captures what it felt like to write the book - and how it must feel to read it. My response will focus first on the questions of how and why we write intellectual history, then on how we should think about the history of democracy, and finally on a few of my principal arguments, addressing along the way some of the criticisms of Bourke, de Dijn, Rodgers, and Winterer. I argue that a culture of democracy requires humility and a willingness to tolerate different perspectives, qualities equally important in our scholarly community of discourse. Despite my disagreements with some characterizations of Toward Democracy, I have tried to keep that in mind.

Because I have been writing about methods in intellectual history for thirty years, I cannot rehearse those arguments in detail here. ${ }^{2}$ The fundamental point of the approach I call pragmatic hermeneutics is that it is possible to write history faithful to the evidence that also contributes to contemporary debates. In short, I believe that "philosophical history" is neither an oxymoron nor, as Bourke suggests, a temptation to be resisted. Instead it has been practiced by many historians, from Tocqueville and Dilthey through Du Bois and Jaurès to Joyce Appleby and Sophia Rosenfeld. Readers will make their own judgments about whether I use that method successfully in Toward Democracy. Bourke and Winterer consider the effort itself misguided, a "category error" of the sort that Stephen A. Douglas accused Abraham Lincoln of making when he introduced ethical considerations into political debates about the Kansas-Nebraska Act.

See James T. Kloppenberg, "Objectivity and Historicism: A Century of American Historical Writing," American Historical Review 94/4 (1989), 1011-30; Kloppenberg, "The Canvas and the Color: Tocqueville's 'Philosophical History' and Why It Matters Now," Modern Intellectual History 3/3 (2006), 495-521; Kloppenberg, "Thinking Historically: A Manifesto of Pragmatic Hermeneutics," Modern Intellectual History 9/1 (2012), 20116; Kloppenberg, "A Well-Tempered Liberalism: Modern Intellectual History and Political Theory," Modern Intellectual History 10/3 (2013), 653-80; and Kloppenberg, "Introduction: Opening American Thought," in Joel Isaac, James T. Kloppenberg, Michael O'Brien, and Jennifer Ratner-Rosenhagen, eds., The Worlds of American Intellectual History (New York, 2016), 1-15. 
Bourke contends that I focus too much on the ethic of reciprocity, that my analysis is "hampered" by my ethical commitments, and that the "philosophy should emerge from the historical narrative" rather than informing it. Winterer contends that I assume that "there is a preexisting, even timeless, 'story' of democracy" that is "relatively easily defined."

$* * *$

In response to these charges, I would like to call attention to two passages from the Introduction. First, "This book does not trace a single concept of democracy from Periclean Athens to Gilded Age America, Victorian England, and the French Third Republic. Instead it examines the diverse meanings of terms used for multiple purposes, terms such as 'democracy,' 'self-government,' and 'popular sovereignty,' to designate a variety of ideas with contested meanings, not only across time but at every historical moment" (3). Rodgers quotes part of the second passage in his essay: "despite widespread agreement about the desirability of democracy now, it would be antihistorical to assert the adequacy of a single understanding of what democracy has meant, not only across the time span of several centuries but also within individual nations. Disagreements about democracy constitute its history" (5).

Having written a long book devoted to examining, in considerable detail, just those disagreements, and the subtle differences as well as similarities among thinkers and activists, I am surprised that the "struggle" is thought to be missing and that the ideas discussed in Toward Democracy are said to be "conflated." Atlantic cultures have approached their conceptions of democracy as travelers approach horizons. As they have moved toward it, it has always receded, and it always will. What Bourke and Winterer are calling teleology seems to me instead simply to be history, the effort to understand and explain change over time.

$* * *$

Evidently I failed to make sufficiently clear that the three-dimensional analytic framework presented in the Introduction to help readers understand the basic components of democracy-institutions (constitutional government, majority rule, and agreed-upon procedures for selecting office holders), principles (popular sovereignty, autonomy, and equality), and premises (deliberation, pluralism, and reciprocity) —emerged from the historical materials I have been wrestling with since I began work on my dissertation in 1977. Far from being imposed on the evidence, that analytic framework took shape over forty years of teaching and research on democracy in Europe and America. I am convinced that it can be used, without distortion or inaccuracy, to extract elements from the historical record—in Winterer's apt image, like iron filings drawn to a magnet— to 
construct a coherent interpretation of developments over an extended period of time. My history of democracy is self-consciously both a contribution to scholarly discourse, intended to clarify and revise understandings of ideas in history, and an intervention into debates about the meaning of self-rule in our own day, debates that so often ignore the cultural preconditions on which democracies historically have depended.

For some historians, diving into the archives is worthwhile primarily because it yields new information that illuminates the past we describe. I respect that conception of historical scholarship, but I do not share it. I believe our goal is to understand the past, both on its own terms and, deliberately and explicitly, in relation to the present. Unlike scholars faithful to the strictures against "anachronism" and "prolepsis" laid down nearly five decades ago by Quentin Skinner, I consider those aims complementary, not contradictory. Historians' judgments and convictions always and inevitably inform our writing. Do we admit it or try to conceal it?

\section{$* * *$}

How should we understand the meaning of democracy? Must we find the word itself in order for our inquiry to have historical integrity? If so, then acknowledging how different were understandings of popular government in the worlds of ancient Athens and Rome is a good place to start. Greeks used the words demos and kratos, Romans the Latin res and publica. The traditions of what have been called democratic and republican thought developed from those distinct starting points. Toward Democracy shows how those traditions intermingled with each other, and with other traditions, in ways sometimes missed by scholars inclined to divide up ideas much more neatly than did many of the writers they study.

It is possible to bring these two historical and linguistic traditions into conversation, as Toward Democracy does and as Bourke and his coeditor Quentin Skinner do in their splendid essay collection Popular Sovereignty in Historical Perspective (2016). The essays show how different thinkers, at different times, have argued over the idea that sovereign authority rests with the people, which is what I mean by using the umbrella term "democracy." But isn't it necessary, as Bourke and Winterer both insist, to distinguish Greek from Latin, "democratic" from "republican"? No, it is not. In Bourke's Introduction to Popular Sovereignty, he observes sensibly that "etymology ... is not a sufficient guide to meaning." To reach historical understanding across time and cultures, we must look carefully at specific debates, waged in a particular time and place and language, and then, if we wish to understand how ideas change, move across those particular discourses to see both connections and differences. Bourke's Introduction proceeds from Athens to Rome, from Marsiglio's ideas to Jean Bodin's, from the English Civil 
War to the American Revolution, and then to the French Revolution, nineteenthand twentieth-century German theorists of popular sovereignty, and anticolonial ideas about democracy. He fits these diverse ideas together as he suggests how they developed, differed, and changed over time. Bodin, Bourke writes, "turned his attention to Athens and Rome, 'les plus grandes Républiques populaires' that had ever existed," and observes that the "identification of popular sovereignty with democracy therefore begins with Bodin," who constructed "the key elements of the modern concept" of popular sovereignty "out of classical materials." In other words, acknowledging the mixture of Greek and Roman-or "democratic" and "republican"-traditions, as I do in Toward Democracy, has been conventional in analyses of self-government since at least $1538 .^{3}$

Some of the contributors to Bourke and Skinner's collection, all distinguished scholars who specialize in the periods they discuss, stick close to the words and arguments of individual thinkers, as does Melissa Lane in her fine essay on Aristotle. Others range broadly, as does Duncan Kelly as he moves seamlessly, and instructively, from Hobbes to Rousseau and from Kant and Hegel to Bluntschli. Bourke's Introduction and several of the essays in Popular Sovereignty illustrate the accuracy of Rodgers's judgment in his contribution to this forum: "tightly constructed political 'languages" that historians of "republicanism" or "liberalism" once used "are a thing of intellectual history's past." ${ }^{4}$ RIP.

There are many ways to do intellectual history, from microscopic analyses that emphasize particularity or "rupture," or authorial intent, to sweeping interpretations that emphasize both continuity and change across centuries and cultures. Such studies will not show the same qualities; all of us need not write

Richard Bourke, "Introduction," in Richard Bourke and Quentin Skinner, eds., Popular Sovereignty in Historical Perspective (Cambridge, 2016), 1-14, at 1, 3.

4 See Richard Bourke and Quentin Skinner, Popular Sovereignty, 1-14, 52-72, 270-96. Winterer contends that I have "nothing to say" about the relation between "republican" and "liberal" ideas in Toward Democracy, The entire book is an attempt to shift our focus from those fruitless debates, and pages $252-453$ of the book elaborate, and provide evidence in support of, arguments first advanced in three articles written toward the end of the debates to which she refers: James T. Kloppenberg, "The Virtues of Liberalism: Christianity, Republicanism, and Ethics in Early American Political Discourse," Journal of American History 74/1 (1987); Kloppenberg, "Republicanism in American History and Historiography," La revue Tocqueville/Tocqueville Review 13/1 (1992); and Kloppenberg, "Knowledge and Belief in American Public Life," in William M. Shea and Peter A. Huff, eds., Knowledge and Belief in America: Enlightenment Traditions and Modern Religious Thought (1995). All three essays are reprinted in James T. Kloppenberg, The Virtues of Liberalism (New York, 1998), 21-37, 38-58, 59-70, notes at 183-201. 
history of the same kind. Bourke implies that there is something deficient in my twenty pages on the ancient world, but I think that readers will see more similarities than differences between his account and mine on pages $27-45$ of Toward Democracy. Both of us cite the same texts and stress the role of Herodotus, of later critics of popular government such as the Old Oligarch, and of Aristotle and Thucydides in shaping later understandings of Athenian democracy. We also agree that Roman writers had little to say about what Bourke calls "democracy as a regime form" - and not only because they had no access to the Greek word, which did not enter European vocabularies until Dominican friars translated Aristotle's texts in the thirteenth century. Even though they did not refer to "democracy," Roman writers' ideas about res publica did prove seminal, often in eclectic combinations with Greek and Christian ideas, for later debates about self-rule.

Some uneasiness about my analysis of the ancient world might relate to my emphasis on the importance of religious faith in democratic discourse. Many historians have observed that the earliest Greek texts recording popular involvement in civic life, in the selection of some officials by election and others by lot, reflected attitudes toward fate, and toward gods, that are hard to square with later attributions of rational thinking to classical Athens. Likewise, it is uncontroversial to observe that early Christians' ideal of benevolence departed from the value that Romans attached to honor and physical courage. As unintelligible as it may be for contemporary historians who think in secular terms, many Europeans and Americans, from the ancient world through the end of the nineteenth century, took seriously ideas about the gods' favor or God's will.

\section{$* * *$}

When religious ideas, as varied and contested as any others, are removed from historical analysis, or when only those who rejected theism are considered worth studying, something crucial is lost. De Dijn is correct to contrast my analysis of the Enlightenment with that of Jonathan Israel, who associates religious belief, even that of eighteenth-century Deists, with obscurantism and ignorance. The historical record shows that not all influential ideas about democracy originated with Baruch Spinoza and his followers, who are now familiar to us thanks to Israel's extraordinary scholarship. I thought it was time to shift our focus, largely for the reasons Anthony La Vopa laid out in the brilliant 2009 review essay in the Historical Journal, which de Dijn and I both cite. I have another reason to be grateful to Israel: his four thick volumes on the Enlightenment make my book on democracy seem almost svelte.

Winterer considers the idea that we should "treat all persons with respect" one formulation of the ethic of reciprocity that I treat as central to democracy“jarringly modern." I disagree. Two millennia ago, Hillel put the point this way: 
"What is hateful to thee, do not unto thy fellow man; this is the whole law." Matthew's Gospel and Paul's Epistles compress the message of Jesus into two commands: love God and love your neighbor as yourself (41). Nothing similar appeared in Greek or Roman texts. Some of the many European and American thinkers who took seriously the Christian ideal of agape included Puritans on both sides of the Atlantic, Locke, Jefferson, Smith, Sieyès, Wollstonecraft, and Lincoln. Pace Winterer, Tocqueville knew that he did not invent the ethic of reciprocity practiced in New England juries and town meetings, and he believed, as I do, that antebellum defenders of slavery betrayed the "ethic of Christianity" they trumpeted. Projecting atheism from our day back to earlier thinkers may be almost reflexive for many scholars today, but it is not historically defensible. Although many Christians followed Augustine's injunction to keep separate the city of God from the city of man, others worked to bring them together.

\section{$* * *$}

Of course not all those who championed democratic ideas professed the same religious ideas_or any religious ideas - as Israel has shown, and as I show in Toward Democracy. Until the end of the nineteenth century, few Roman Catholics saw democracy as anything but the work of the devil. Luther backed away from the idea of popular government as soon as some of his followers embraced it. Rousseau, whom de Dijn correctly describes in her contribution to this forum as "the eighteenth century's most important democratic thinker ... who emphasized more eloquently than any other philosophe the ethic of reciprocity and the value of autonomy" pointed out that historically Christianity had bolstered tyranny and "bred intolerance." I argue that the French Revolution foundered when it devolved into a religious war, primarily because the Civil Constitution of the Clergy, judged necessary due to the intransigence of the French Catholic hierarchy and their aristocratic allies, required priests to declare fealty to the republic. That step turned members of male and female religious orders, and even lay Catholics who favored reforming or replacing the monarchy, into implacable counterrevolutionaries. A gulf clearly divided the institutionalized form assumed by the Roman Catholic Church from the original thrust of the Christian scriptures. Yet much of the criticism directed against absolutism, and against hierarchy more generally, derived from the egalitarian ethos of the Gospels, from Luther's insistence on the equality of all believers, and from Calvinists' predilection for self-governing congregations of saints. Evidence sustaining that argument runs throughout Toward Democracy.

As I immersed myself in the evidence, another surprising finding was the pervasiveness of assumptions concerning the legitimacy, necessity, and desirability of representative democracy, which many scholars in the last half-century 
have dismissed as a contradiction in terms. Universal and direct participation, whether through mass action or through plebiscites, is now often considered a defining feature of what Bourke contends "we would recognize as democracy today." 5 Among the principal aims of Toward Democracy is to demonstrate just how widespread support for representation was from the seventeenth through the nineteenth century. Even at the height of the English, American, and French Revolutions, almost everyone-including Thomas Paine-agreed that representative government is required in any polity larger than a small village. Of course disputes over the meaning, purpose, and mechanics of representation raged. As Rodgers points out, questions of exclusion and inclusion, who is competent to vote and hold office and who is not, and what officials are empowered to do in the people's name, have been central issues in debates about democracy. Detailed examination of those disagreements is at the core of my analysis.

$* * *$

Toward Democracy issues challenges to the accepted wisdom on many particular issues, and I want to mention just a few before concluding. I understand why historians now emphasize the intolerance and inequalities evident in colonial New England, yet that reorientation has caused the Puritans' self-conscious experiments in "democracie" (their word, not mine) to fade out of focus. Winterer correctly stresses the importance of Tocqueville's New England informants, as do I, but he was nevertheless correct to call New England "the cradle of democracy." The contrasts between the contentious practices of self-rule that flourished in these little commonwealths and the English Puritans' inability to establish equally radical democratic institutions, which they fought and died to achieve in the English Civil War, merit more attention than they have received from historians in recent years.

Toward Democracy also focuses on the gap between the radical ideas of Algernon Sidney and John Locke and the limited effect on popular government of the "Glorious Revolution" of 1688 , especially when it is compared with the continuing development of de facto self-rule in the North American colonies. In Massachusetts, John Wise, one of the most important legal theorists of the early eighteenth century, drew on Plutarch as well as Calvin to characterize the original form of government as "democratical," dismissed all other forms as degenerate, and saw his law code adopted by the electorate of the Commonwealth. My treatment of Enlightenment ideas, as both de Dijn and Winterer note, focuses attention on Rousseau, on Scottish thought, and on the influence of Henry

Richard Tuck, The Sleeping Sovereign: The Invention of Modern Democracy (New York, 2015), exemplifies this approach to democracy. 
May's "moderate Enlightenment" rather than on the currently more fashionable radical fringe. That choice reflects my conviction that accounts of the American Revolution and the founding of the new nation have become unbalanced.

$* * *$

While I emphasize the hierarchies of gender and race that persisted in the new nation, and the fact that the US Constitution solidified the preexisting regime of white male supremacy, imputing to thinkers such as the young John Adams, Jefferson, Madison, and James Wilson ideas of elite domination of ordinary people requires overlooking most of what they wrote. These thinkers, as I show in Toward Democracy, had much more in common with Rousseau than with Hamilton. Like Rousseau, who wrote constitutions for Poland and Corsica incorporating representation, they envisioned a complex representative democracy resting on a culture imbued with commitments to equality, autonomy, and the common good rather than hierarchy, freedom from all constraints, and the simple balancing of competing interests. That argument may be controversial, but along with Rodgers and de Dijn I believe that the evidence in my book sustains it.

Bourke seems not to have engaged with my analysis of American democracy. His essay includes only a single reference to an American, and his comment on Madison's Federalist 10 gets my argument-and Madison-wrong, as Rodgers makes clear when he acknowledges how inaccurate is the long-conventional view of Madison as interested only in "controlling" the people. Given Bourke's own fine scholarship on Edmund Burke and his work editing Eric Nelson's essay in Popular Sovereignty, his failure to grapple with the hundreds of pages of evidence concerning eighteenth- and nineteenth-century American thought presented in Toward Democracy seems odd. The argument of Toward Democracy does not proceed by "association" or "analogy" but rests on sustained analysis of evidence drawn from the texts produced by Americans who acknowledged their explicit use of the ideas of European thinkers from Aristotle and Cicero through Sidney, Locke, Montesquieu, and Rousseau to Smith and Hume.

\section{***}

Chapters 7-9 of Toward Democracy supplement and complicate the arguments of a generation of historians whose work has enriched our understanding of the social dynamics of late eighteenth-century North America. Their tireless prosecution of the "elites" who allegedly stole the Revolution from "the people," however, has turned thinkers who worked to advance a culture of representative democracy into cartoon characters. The political writings of the young Adams, Jefferson, Madison, and Wilson, among the most enduringly influential texts 
produced from the sixteenth through the nineteenth centuries, look very different when they are viewed in relation to Smith's idea of sympathy and Rousseau's idea of the general will rather than through the distorting lenses of post-World War II liberal pluralists. This influential generation of American political scientists, who conceived of government as the balancing of competing interest groups, projected their own ideas back to Adams and Madison in particular. Like Smith's Theory of Moral Sentiments, Rousseau's Social Contract had a much greater impact in North America, where it was more widely read and respected (rather than "traduced," at least until Robespierre explicitly invoked it to justify the Terror) than recent scholars have appreciated. I look forward to further investigations of the similarities and differences among these ideas rather than dismissals of these American thinkers as enemies of the people.

Among French historians, tracing the economic woes of the Ancien Régime to the cost of securing American independence is hardly controversial. Likewise the idea that a "contagion of liberty" spread from Boston, Philadelphia, and Williamsburg to Paris and beyond, and exerted influence, often through Loyalists who left the new nation for Canada or England, did not originate with $R$. R. Palmer but with eighteenth-century European observers. It too has become conventional. ${ }^{6}$ The question of why democracy in America stabilized and slowly expanded while the French and Haitian Revolutions ended in successive tyrannies, by contrast, may never be resolved. Toward Democracy offers an explanation in multiple dimensions. Some have to do with French subjects' lack of experience with self-rule and Americans' century and a half of practice. Others have to do with the ways in which more radical challenges to exclusionary white supremacy, represented by the Haitian and French Revolutions, were successfully contained. In Europe that work was done by resurgent aristocracies and bolstered by reactionary popular movements; in the US by the Herrenvolk democracy cemented by mainstream figures in the Jackson Party and left all but unchallenged until Lincoln forced the issue in the necessary but nevertheless catastrophic US Civil War.

\section{$* * *$}

After that war, many Americans feared that the nation's democratic promise would never be fulfilled. Walt Whitman, whom Winterer invokes as a champion of what she calls "ungovernable ... selves," worried about just that prospect. $\mathrm{He}$ recommended, in the essay that provides Winterer's title and that I cite in the

See Maya Jasanoff, Liberty's Exiles: American Loyalists in the Revolutionary World (New York, 2011); and Janet Polasky, Revolutions without Borders: The Call to Liberty in the Atlantic World (New Haven, 2015). 
concluding pages of Toward Democracy, that Americans "look our times and land searchingly in the face, like a physician diagnosing some deep disease." The disease was untrammeled individualism, which Whitman, like Tocqueville, Mill, and Lincoln, deemed antithetical to democracy, and which Whitman contrasted to the "moral conscience" and "adhesiveness or love, that fuses, ties, and aggregates" (quoted at 707-8). It was not simple freedom from all constraints but autonomyliberty bounded by law and community — that Whitman, drawing on Hegel but also echoing Rousseau, Madison, and many of the other thinkers discussed in Toward Democracy, deemed necessary for individual as well as political self-rule.

Rodgers raises one more question that will never be resolved: how much compromise is too much? Indeed, the perennial tension between the calm toleration of differences and the courage of steadfast conviction is unresolvable in democracies, not only in practice but even in principle. Democracy, I contend, has always required balancing competing ideals, which is why it has always troubled utopians and radicals on all sides of every question. Democracy requires humility, moderation, and acceptance of the impossibility of ever reaching stable comity, let alone consensus. The alternative to compromise is civil war, the toxic consequences of which endure for centuries. Unquestionably it has been passionate democratic activists certain of their rectitude; Puritans such as Roger Williams and Richard Overton; advocates of women's rights such as Mary Wollstonecraft and Harriet Taylor Mill; antislavery radicals such as Anthony Benezet, Henry David Thoreau, and Frederick Douglass; and revolutionary firebrands such as the young John Adams and Maximilien Robespierre who have driven popular government forward. But that passion, necessary as it is, can corrode the cultural predispositions on which democracy depends. Democracy is always imperfect and unstable.

$* * *$

For centuries, people in the North Atlantic have been moving toward the horizon of democracy, even though they never arrive and never even agree on its meaning. The history of democracy is the history of those disagreements, which stretch from the ancient world until today. That is why I resist both Marxist and Whiggish teleologies (such as Grote's) and question the claim that an implicit teleology is discernible in my analysis. I argue instead that democracy is necessarily indeterminate because the will of the people is never unitary and always unpredictable. That is also why I emphasize irony-the unintended consequences of choices and decisions - to make sense of the story I tell. Of course the thinkers whose ideas I examine did not think of themselves as actors in a tragedy, as Winterer observes. Nor did many of them show much awareness of the unintended consequences of their actions, although Tocqueville, Mill, and 
Lincoln surely did. That perspective is usually available only afterward, when a form of life has grown old, as Hegel put it, and history paints its gray on gray. But other thinkers examined in Toward Democracy, including the English Levellers, Adams, Jefferson, Madison, Condorcet, de Gouges, Wollstonecraft, and Douglass, lived to see their ideas about the promise of democracy betrayed by many who called themselves democrats.

Today many people in the North Atlantic, across the political spectrum, "have lost sight," in de Dijn's words in this forum, of the "broader, ethical dimension of self-government." They are unwilling to accept the legitimacy of democratic institutions; uncomfortable with the principles of equality and autonomy; and contemptuous of the ideals of deliberation, pluralism, and reciprocity. If commitments to those components of self-rule continue to fade, I fear that we will find ourselves moving away from democracy. At that point, defenders of self-government will need to understand that a healthy democracy requires not only the rule of law and institutions for moderating conflict but also the dispositions of humility, tolerance, and mutual respect. 